Archive for

Organic Chemistry

Arkivoc 2017, part iv, 249-264

\title{
Larger laboratory scale synthesis of 5-methyluridine and formal synthesis of its L-enantiomer
}

\section{Luciano J. Hoeltgebaum Thiesen, ${ }^{a}$ Nadia Cabral, ${ }^{a}$ Maria Joselice e Silva, ${ }^{b}$ Gilson Bezerra, ${ }^{c}$ and Bogdan Doboszewski ${ }^{d^{*}}$}

${ }^{a}$ Departamento de Farmácia, Universidade Federal de Pernambuco, Recife, PE, 50740-521, Brasil ${ }^{b}$ Departamento de Farmácia, Universidade Federal do Rio Grande do Norte, Natal, RN, 59010-090, Brasil 'Instituto Federal de Educação, Ciência e Tecnologia de Pernambuco, Barreiros, PE, 55560-000, Brasil

${ }^{d}$ Departamento de Química, Universidade Federal Rural de Pernambuco, Recife, PE, 52171-900, Brasil E-mail: bdoboszewski@hotmail.com

Received 03-19-2017

Accepted 05-07-2017

Published on line 05-29-2017

\section{Abstract}

A larger laboratory scale synthesis (>60 g per run) of 5-methyluridine is presented. The critical intermediate 1,2-O-isopropylidene- $\alpha$-D-ribofuranose was prepared from very cheap D-glucose via D-allose. Its L-enantiomer was obtained from L-arabinose via L-glucose, and also from L-xylose.
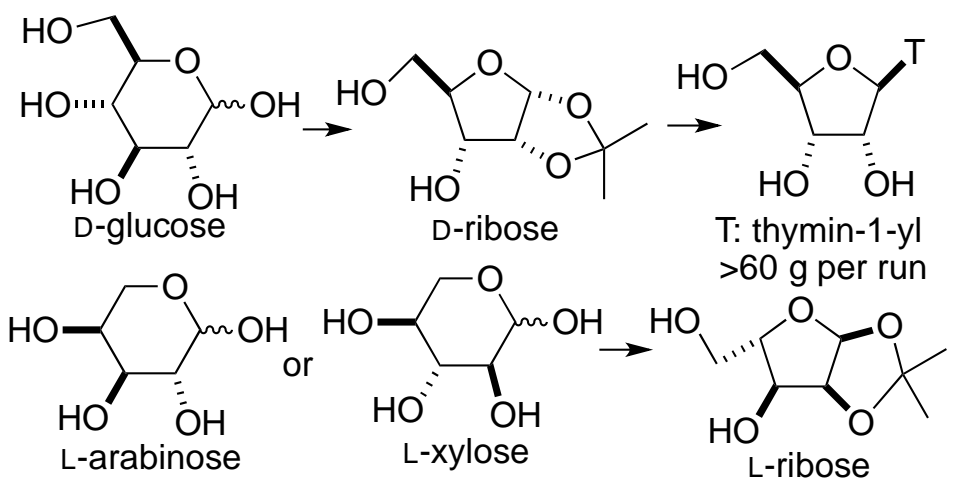

5-Methyluridine was prepared from D-glucose via

1,2-isopropylidene- -D-ribofuranose as intermediate, the

L-enantiomer of which was prepared from L-arabinose via L-glucose,

and independently from L-xylose.

Keywords: 5-Methyluridine, chiral pool, stereoselective synthesis, D- and L-carbohydrates 


\section{Introduction}

5-Methyluridine 1 is a component of the ribonucleic acids from which it can be isolated, however demand for it far exceeds a supply in this way. 5-Methyluridine is a starting compound for the synthesis of 3'-azido-2',3'dideoxythymidine or AZT (Zidovudine, Retrovir) 3 (via 2'-deoxy compound 2) and also to obtain 2', $3^{\prime}$-dideoxy$2^{\prime}, 3^{\prime}$-didehydrothymidine or d4T (Zerit) 4, both used as potent inhibitors of the reverse transcriptase, a critical enzyme necessary for multiplication of the HIV virus responsible for the AIDS epidemic. ${ }^{1}$ The sugar moieties present in 1-4 belong to the $D$ series. L-Thymidine 6 is very active inhibitor of the reverse transcriptase of the hepatitis B virus (HBV). ${ }^{2}$ Compound 6 is marketed under the name Telbivudine (Sebvio, Tyzeka) and is the enantiomer of $\mathbf{2}$. As such it can be prepared from the $L 5$-methyluridine $\mathbf{5}$ via deoxygenation at its $\mathbf{2}^{\prime}$-position. ${ }^{3}$ Considering the demand for both enantiomers $\mathbf{1}$ and $\mathbf{5}$, uniform access to both of them is an attractive synthetic goal.

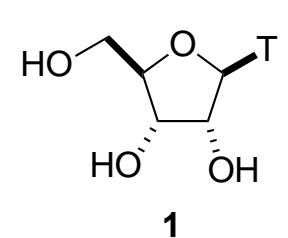

1

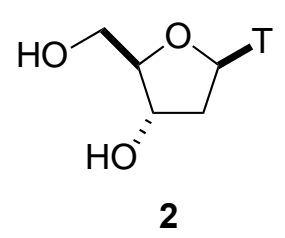

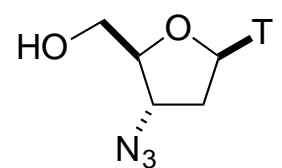

$3 \mathrm{AZT}$

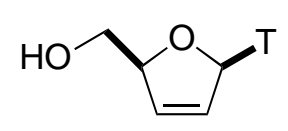

$4 \mathrm{~d} 4 \mathrm{~T}$
$\mathrm{T}:$<smiles>CCn1cc(C)c(=O)[nH]c1=O</smiles>

thymin-1-yl

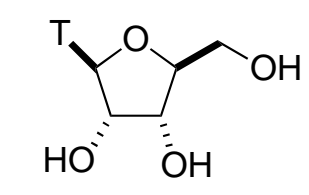

5 L 5-methyluridine

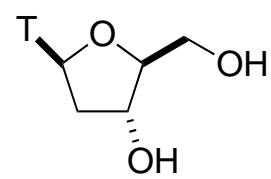

6 Telbivudine

The stereochemical characteristics of 1,2;5,6-di-O-isopropylidene- $\alpha$-D-glucofuranose 7 permit its transformation into 1,2-O-isopropylidene- $\alpha$-D-ribofuranose $12^{4}$ and further to 1 - $O$-acetyl-2,3,5-tri-O-benzoyl$\beta$-D-ribofuranose 15 and finally to 5-methyluridine 1 . It is obvious that the same sequence of reactions performed on L-glucose will furnish $\mathrm{L}$ 5-methyluridine $\mathbf{5}$. Compound $\mathbf{1 5}$ can be directly prepared form D-ribose using $\mathrm{HCl}-\mathrm{MeOH}(\rightarrow 13),{ }^{5,6} \mathrm{H}_{2} \mathrm{SO}_{4}-\mathrm{MeOH}^{7}$ or $\mathrm{AcCl}-\mathrm{MeOH}^{8}$ followed by benzoylation $(\rightarrow 14)$ and acetolysis $(\rightarrow$ 15), but since D-glucose is abundant and is one of the cheapest chiral compounds available, we used it to obtain D-ribose and finally 1 at a larger laboratory scale (> $60 \mathrm{~g}$ per run) in excellent cumulative yields of ca. $90 \%$ for the sequence $15 \rightarrow 17 \rightarrow 1$. We also tried to obtain $1,2-O$-isopropylidene- $\alpha$-L-ribofuranose 32 using Lglucose which was obtained from L-arabinose via the nitromethane one-carbon extension (Fischer-Sowden reaction ${ }^{9,10}$ which is a carbohydrate version of the Henry reaction, ${ }^{11-15}$ ) followed by a Nef reaction (sodium aci salt of nitroalditols, $\left.\mathrm{H}_{2} \mathrm{SO}_{4}\right) .{ }^{10}$ The other versions of this process include ozonization, ${ }^{16,17}$ and peroxomolybdate$\mathrm{H}_{2} \mathrm{O}_{2} ;{ }^{17,18}$ non-carbohydrate examples include among others "basic silica gel", ${ }^{19} \mathrm{NaClO}_{2}{ }^{20}$ and $\mathrm{H}_{2} \mathrm{O}_{2}-\mathrm{K}_{2} \mathrm{CO}_{3}{ }^{21}$ the Nef reaction has been recently reviewed. ${ }^{22,23}$ This met with a limited success due to difficulties in separation of the necessary L-glucose $\mathbf{2 7}$ from the L-mannose $\mathbf{2 8}$ by chromatography (see below). A much better result was obtained using reasonably priced L-xylose which was converted to the L-ribose $\mathbf{3 2}$ in batches of ca. $15 \mathrm{~g}$ per run. Since $\mathbf{3 2}$ can be elaborated to produce $L$-methyluridine $\mathbf{5}$ by the same set of conditions as those applied to reach 5-methyluridine $\mathbf{1}$ from the D-ribose 12, we can claim that a formal synthesis of $L \mathbf{5}$ was also realized. 


\section{Results and Discussion}

A transformation of D-glucose into D-ribose via inversion of the configuration at the C3 position followed by fission of the $\mathrm{C} 5-\mathrm{C} 6$ bond (dehomologation) is known, and we followed the published procedures with some additional modifications. Alternative methods to produce D-ribose have been reviewed. ${ }^{24}$ The critical inversion of configuration at the C3 position of D-glucose to get D-allose $\mathbf{9}$ requires the transient ulose $\mathbf{8}$. Reduction of $\mathbf{8}$ proceeds with practically complete stereoselectivity $(\rightarrow 9)$ using $\mathrm{NaBH}_{4}$ but application of the $\mathrm{LiAlH}_{4}$ gives mixtures of $\mathbf{7}$ and $\mathbf{9 .} .^{25}$ Some care must be exercised during the oxidation step $(\mathbf{7} \rightarrow \mathbf{8})$. The cheapest and operationally easiest oxidant is DMSO-Ac ${ }_{2} \mathrm{O}$ mixture, ${ }^{26}$ even though foul smelling divalent sulfur compounds are formed. The other oxidants include $\mathrm{DMSO}-\mathrm{P}_{2} \mathrm{O}_{5},{ }^{27}$ pyridinium dichromate- $\mathrm{Ac}_{2} \mathrm{O}^{28}$ pyridinium chlorochromate, ${ }^{29}$ and $\mathrm{RuCl}_{3}-\mathrm{NaIO}_{4}{ }^{30}\left(\mathrm{RuO}_{2}-\mathrm{NaIO}_{4}{ }^{31}\right.$ was reported to also form Baeyer-Villiger overoxidation products) and finally Dess-Martin periodinane. ${ }^{32} \mathrm{DMSO}-\mathrm{Ac}_{2} \mathrm{O}$ is not a very active system and its application may result in incomplete conversion of $\mathbf{7}$ into $\mathbf{8}$, and consequently, the next reduction step may furnish a mixture of the allose $\mathbf{9}$ and unreacted glucose 7, which are difficult to separate. In fact, unreacted 7 was reported to be present even after $24 \mathrm{~h}$ of reaction time. ${ }^{26}$ The same kind of problem has been observed before in different context. ${ }^{33}$ The very active $\mathrm{CrO}_{3}-\mathrm{Py}_{-} \mathrm{Ac}_{2} \mathrm{O}$ mixture ${ }^{34}$ provided complete oxidation in less than 1 hour at room temperature for 25-39 g batches of 7. A weak point of this method is formation of insoluble tars composed of the reduced chromium compounds complexed with pyridine. A very interesting one-pot oxidation-reduction procedure was published which consists of the addition of the $\mathrm{NaBH}_{4}$ directly to the DMSO-oxalyl chloride oxidation mixture, ${ }^{35}$ although this was performed on small scale. The dehomologation step $(9 \rightarrow 10 \rightarrow 11 \rightarrow 12$ ), i.e. a transformation of the D-allose (a hexose) to D-ribose (a pentose) can be performed using orthoperiodic acid $\mathrm{H}_{5} \mathrm{IO}_{6}$ followed by $\mathrm{NaBH}_{4}$ reduction. ${ }^{36,37}$ The orthoperiodic acid is strong enough ( $\mathrm{pKa}$ ca $3.3^{38}$ ) to promote a hydrolysis of the more reactive C5-C6 acetonide in $\mathbf{9}$ to liberate a diol $\mathbf{1 0}$ which was subsequently cleaved by the same reagent to furnish the aldehyde $\mathbf{1 1}$ which in turn was subjected to $\mathrm{NaBH}_{4}$ reduction to yield the ribo compound 12. This procedure is very attractive and in fact it was successfully used on a small scale $(1 \mathrm{~g})$ in good yields (e.g. 29 $\rightarrow$ 32, see below). When applied to 9 at a $27 \mathrm{~g}$ scale however, it furnished the 1,2-O-isopropylidene- $\alpha$-D-ribofuranose $\mathbf{1 2}$ in yield as low as $25 \%$. The reason for this is unclear, but probably can be traced to incomplete removal of the iodic acid $\mathrm{HIO}_{3}$ formed during oxidation of the $\mathrm{C} 5-\mathrm{C} 6$ diol. $\mathrm{HIO}_{3}$ crystallized in the reaction mixture and must have been filtered off. In the case of incomplete crystallization and removal, $\mathrm{NaBH}_{4}$ reduced it to the transient hypoiodous acid ${ }^{39}$ which presumably degraded the aldehyde $\mathbf{1 1}$ oxidatively. To avoid this it was much better to perform separately the hydrolysis $(9 \rightarrow 10)$ using $0.8 \% \mathrm{H}_{2} \mathrm{SO}_{4}$ in $\mathrm{MeOH}-\mathrm{H}_{2} \mathrm{O}$ mixture ${ }^{40}$ followed by $\mathrm{NalO}_{4}$ oxidation $(\rightarrow 11)$ and final $\mathrm{NaBH}_{4}$ reduction to get the 1,2-O-isopropylidene- $\alpha$-D-ribofuranose 12 in much better yield $(\mathbf{9} \rightarrow \mathbf{1 2}, 76 \%)$. Removal of the acetonide $\left(70 \%\right.$ aq. $\left.\mathrm{AcOH}, 80^{\circ} \mathrm{C}\right)$ followed by Fischer type glycosylation $\left(\mathrm{MeOH}, \mathrm{cat} . \mathrm{H}_{2} \mathrm{SO}_{4}\right.$ or $\mathrm{HCl})$ furnished kinetically controlled furanosides 13 which, upon conventional benzoylation (BzCl, $\mathrm{Py}$ ) followed by acetolysis $\left(\mathrm{Ac}_{2} \mathrm{O}, \mathrm{AcOH}\right.$, cat. $\left.\mathrm{H}_{2} \mathrm{SO}_{4}\right)$, furnished the necessary 1-O-acetyl-2,3,5-tri-O-benzoyl- $\beta$-Dribofuranose 15. The best cumulative yields for this sequence was $45 \%$ based on 12 . There are some variations in the published conditions and the yields of $\mathbf{1 5}$ obtained by acetolysis. ${ }^{5,6,41}$ Cimpoia et al. ${ }^{41}$ reported that the best procedure was with a decreased amount of $\mathrm{H}_{2} \mathrm{SO}_{4}$ in relation to $\mathrm{AcOH}$ and $\mathrm{Ac} \mathrm{C}_{2} \mathrm{O}$ and low temperature to avoid formation of the open-chain acetal acetates. Transformations of $\mathbf{1 2}$ to $\mathbf{1 5}$ were performed without isolation of the intermediates. The compound 15 must be thoroughly dried since traces of $i$-PrOH used for its crystallization react with $\mathrm{SnCl}_{4}$ during the next coupling step to liberate $\mathrm{HCl}$ which may compromise the yield of 17. The compound $\mathbf{1 5}$ was finally coupled with the trimethysilylated thymine (thymine, HMDS, cat. $\left(\mathrm{NH}_{4}\right)_{2} \mathrm{SO}_{4}$, bp., 3-4 h) under the influence of $\mathrm{SnCl}_{4}$ in $\mathrm{CH}_{3} \mathrm{CN}^{42}$ to get 2,3,5-tri-O-benzoyl- $\beta$-D-ribofuranosyl 
thymine 17 in nearly quantitative yield. Alternative versions of this coupling include different activating groups at the anomeric position, like chloride, ${ }^{43}$ methylcarbonate, ${ }^{44} 1,2$-epoxide, ${ }^{45} \mathrm{~N}$-phenyl trifluoracetimidate, ${ }^{46}$ or S-tolyl group, ${ }^{47}$ different catalysts like TMSOTf, ${ }^{48} \mathrm{BiBr}_{3}{ }^{49}$ or $\mathrm{Ph}_{3} \mathrm{PAu}^{+}-\mathrm{N}\left(\mathrm{SO}_{2} \mathrm{CF}_{3}\right)_{2},{ }^{50}$ different pattern of protection of the ribofuranosyl moiety like $1,2,3,5$-tetra-O-acetate ${ }^{49}$ or 1,2 -di-O-acetyl-3,5-di-O-benzoate, ${ }^{51}$ different activation of the thymine moiety via bis(tributylstannylation) ${ }^{52}$ rather than bis(trimethylsilylation), and finally a solvent-free ball milling procedure. ${ }^{53}$ Compound $\mathbf{1 7}$ was finally deprotected using Zemplén conditions ( $\mathrm{MeOH}$, cat. NaOMe). Methyl benzoate (an oil) formed during this reaction interferes with the crystallization of 1 and for this reason was removed by partition between $\mathrm{CHCl}_{3}$ and water ( 1 remained in the water phase). The 5-methyluridine 1 formed in this way was isolated in ca $90 \%$ yield for two steps (coupling and deprotection). It is interesting to note that the commercial 1,2,3,5-tetra-O-acetyl- $\beta$-D-ribofuranose 16 under the same coupling conditions furnished 2,3,5-tri-O-acetyl- $\beta$-D-ribofuranosyl thymine 18 in lower yield (69.5\%) even though a clear spot-to-spot reaction also took place. This probably can be attributed to inferior stabilization of the reactive cation 20 in comparison to the benzylic cation 19. Scheme 1 summarizes this part of the project.<smiles>[2H]C1O[C@@H]2OC(C)(C)O[C@H]2[C@H]1O</smiles>

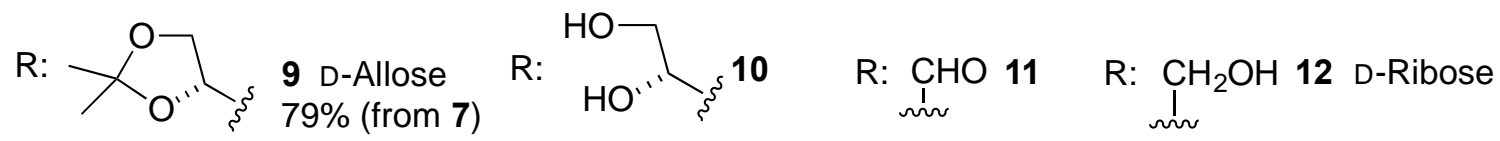

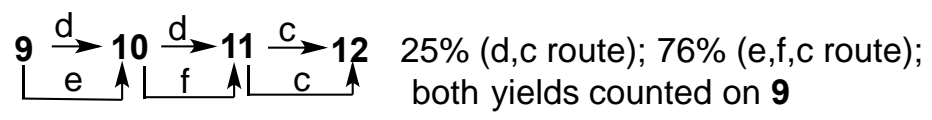

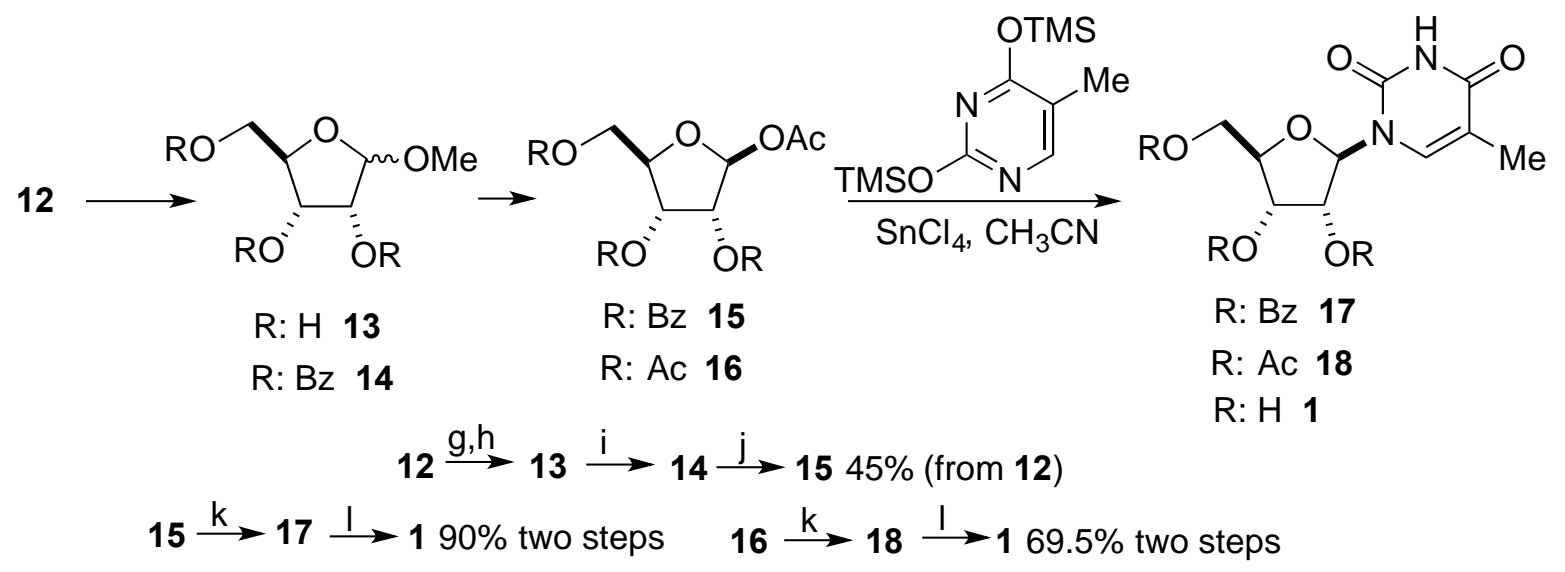

Conditions: a. acetone, $\mathrm{H}_{2} \mathrm{SO}_{4}$; b. DMSO, $\mathrm{Ac}_{2} \mathrm{O}$ or $\mathrm{CrO}_{3}$, $\mathrm{Py}, \mathrm{Ac}_{2} \mathrm{O} ; \mathrm{c} . \mathrm{NaBH}_{4} ; \mathrm{d} . \mathrm{H}_{5} \mathrm{IO}$, one pot; e. $0.8 \% \mathrm{H}_{2} \mathrm{SO}_{4}, \mathrm{MeOH}$; f. $\mathrm{NalO}_{4}$; g. AcOH, $\mathrm{H}_{2} \mathrm{O}$; h. $\mathrm{MeOH}, \mathrm{H}_{2} \mathrm{SO}_{4}$; i. BzCl, Py; j. AcOH, $\mathrm{Ac}_{2} \mathrm{O}, \mathrm{H}_{2} \mathrm{SO}_{4}$; k. (TMS)T, $\mathrm{SnCl}_{4}$; I. MeOH, MeONa<smiles>O=C(O)COC1O[C@@H]2OC(c3ccccc3)O[C@H]2[C@H]1O[Na]</smiles><smiles>CC(=O)OCC1O[C@@H]2OC(C)O[C@H]2[C@H]1OC(C)C</smiles>

Scheme 1. Synthesis of 5-methyluridine 1 starting from D-glucose via D-allose. 
L-Ribose, ${ }^{54,55}$ a necessary substrate to obtain the L 5 -methyluridine $\mathbf{5}$ is a known compound that can be obtained from L-arabinose via epimerization at the C2 position catalyzed by molybdic acid (Bílik reaction), ${ }^{56,57}$ starting from D-fructose, ${ }^{58}$ D-galactose, ${ }^{59}$ D-lyxose, ${ }^{60}$ or D-ribose via transposition of the C1-C5 position. ${ }^{61,62}$ The latter transformation is possible due to the enantiotopic relationship between both $-\mathrm{CH}_{2} \mathrm{OH}$ groups in Dribitol (and also in any alditol which has a plane of symmetry like galactitol or allitol. In fact D-galactose was transformed into L-galactose ${ }^{63}$ by the same kind of transposition). However, having accomplished a synthesis of 1 using D-glucose, we wanted to apply L-glucose for the same purpose to obtain the L enantiomer $\mathbf{5}$. LGlucose can be prepared from D-glucose by the published procedure. ${ }^{64}$ It is also commercially available but due to the prohibitively high price we tried to obtain it from reasonably priced L-arabinose via a one carbon atom extension. This approach is shown in the Scheme 2. The Henry reaction (aldehyde/ketone, nitroalkane, base) ${ }^{9-15}$ performed on L-arabinose and $\mathrm{CH}_{3} \mathrm{NO}_{2}$ and $\mathrm{NaOMe}{ }^{9,10}$ furnished a mixture of crystalline 1-deoxy-1nitro-L-glucitol 21 and 1-deoxy-1-nitro-L-mannitol 22 in approximately equal proportion. This addition to diastereotopic sides of the carbonyl group should follow the Felkin-Anh model ${ }^{65}$ as shown in 23 and 24 (Figure 1) where the $\mathrm{C} 3-\mathrm{C} 5$ fragment is treated as a large group and the $\mathrm{C} 2-\mathrm{OH}$ as a medium one.

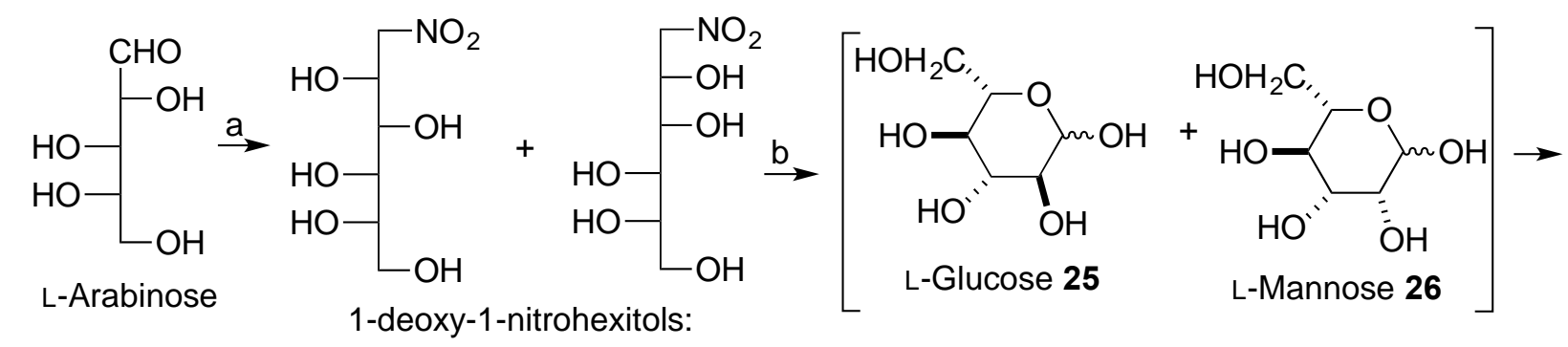

L-gluco $21 \quad$ L-manno 22

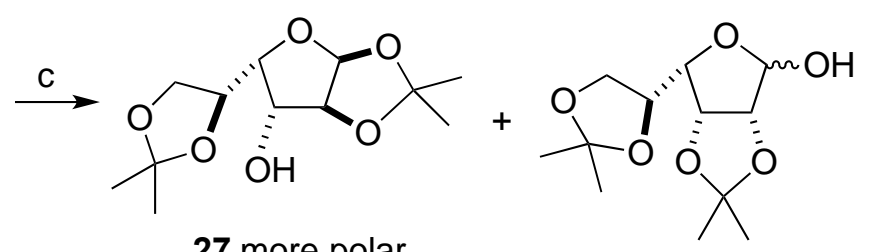

27 more polar, acetonide of L-glucose

28 less polar

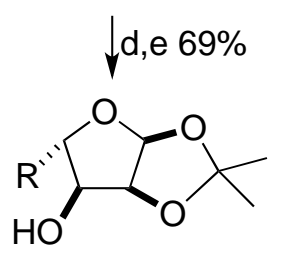
acetonide of L-mannose

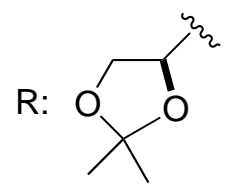

L-allose 29<smiles>[R]CC(C)O</smiles>

30
$\mathrm{R}: \stackrel{n^{2}}{\stackrel{C}{C}} \mathrm{HO}$

31
R: $\sim^{N}$

$\mathrm{CH}_{2} \mathrm{OH}$

L-ribose 32

$$
29 \stackrel{f}{\rightarrow} 30 \stackrel{f}{\rightarrow} 31 \stackrel{e}{\rightarrow} 3269 \% \text { based on } 29
$$

Conditions: a. $\mathrm{CH}_{3} \mathrm{NO}_{2}, \mathrm{NaOMe}$; b. $\mathrm{H}_{2} \mathrm{SO}_{4}, \mathrm{H}_{2} \mathrm{O}$; c. acetone, $\mathrm{H}^{+}$, ultrasound; d. $\mathrm{CrO}_{3}, \mathrm{Py}, \mathrm{Ac}_{2} \mathrm{O}$; e. $\mathrm{NaBH}_{4}$; f. $\mathrm{H}_{5} \mathrm{IO}_{6} 29$ via 30 to 31 , one pot.

Scheme 2. Synthesis of 1,2-O-isopropylidene- $\alpha$-L-ribose 32 starting from L-arabinose. 
A.

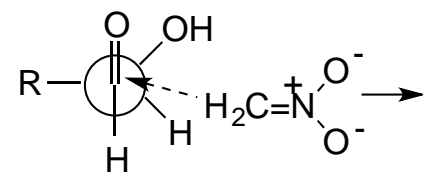

23 Re attack

R: C3-C5 fragment

B.

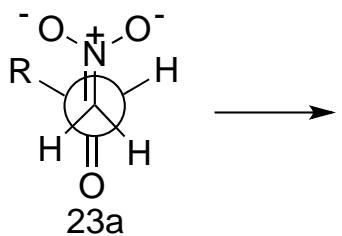

R: C2-C5 fragment

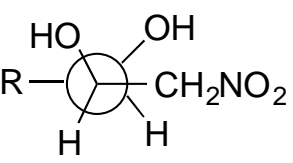

21 configuration $(R)$ at C2: L-glucitol

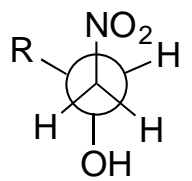

21a configuration $(R)$ at C2: L-glucitol

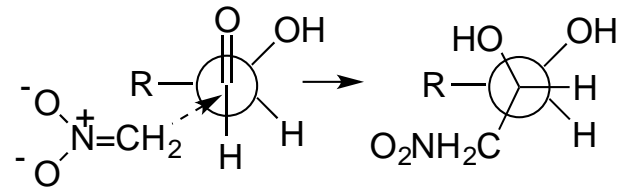

24 Si attack

22 configuration (S) at C2: L-mannitol

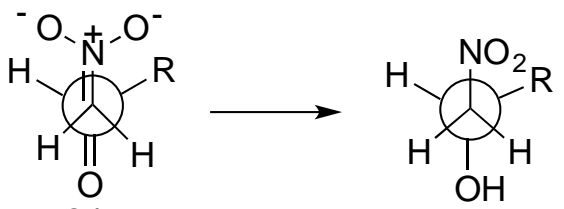

$24 a$

R: C2-C5 fragment 22a configuration (S) at C2: L-mannitol

Figure 1. Stereochemistry of formation of nitroalcohols $\mathbf{2 1}$ and $\mathbf{2 2}$ according to the Felkin-Anh model (A) and according to the ref. 66 (B).

The privileged attack on the Re side should furnish the $\mathrm{R}$ configuration at the $\mathrm{C} 2$ atom, i.e. the L-gluco diastereoisomer $\mathbf{2 1}$ should predominate. It is not a case, though. A reason for this is unclear, but one can consider extensive hydrogen bonding between a solvent $(\mathrm{MeOH})$ and the $\mathrm{C}=\mathrm{O}$ group. This may override the steric and stereoelectronic factors which control the Felkin-Anh transition state. Also, a fully formed carbonyl group might not even have been present. Rather, reactive forms might have been the species with the hemiacetal rings being partially opened with retained $\alpha$ or $\beta$ configuration. This may additionally influence the steric outcome. Theoretical calculations show that the transition states during the Henry reactions are such, that the negatively charged $\mathrm{NO}_{2}$ moiety is far away from the carbonyl oxygen ${ }^{66}$ atom as in 23a and 24a which apparently have the same energies. Consequently, both epimeric products $\mathbf{2 1}$ and $\mathbf{2 2}$ are formed without much stereoselection. This is additionally influenced by reversibility of the addition in basic medium. Irrespective of the mechanism, there is no preference for $\mathbf{2 1}$ over $\mathbf{2 2}$. The 21/22 mixture was described as being separable by tedious fractional crystallization ${ }^{9,10}$ and the resulting 1-nitro-L-glucitol and 1-nitro-Lmannitol were subjected separately to the Nef reaction to give L-glucose and L-mannose, respectively. However, since we needed the 2,3;5,6-di-O-isopropylidene-L-mannofuranose for another project we performed the Nef reaction (a. 21/22, $\mathrm{NaOH} ;$ b. $\left.\mathrm{H}_{2} \mathrm{SO}_{4}\right)^{10}$ without fractional crystallization. A mixture of Lglucose 25 and L-mannose 26 thus obtained was subjected to isopropylidenation (acetone, $\mathrm{H}_{2} \mathrm{SO}_{2}$, ultrasound $)^{67}$ to yield a mixture of the di-O-isopropylidenated compounds $\mathbf{2 7}$ and $\mathbf{2 8}$ which were separated by vacuum-dry chromatography ${ }^{68,69}$ at this stage. Eluted first was the L-mannose $\mathbf{2 8}$ followed by more polar Lglucose 27. The NMR characteristics of both $\mathbf{2 7}$ and $\mathbf{2 8}$ are identical to those of their D-enantiomers. Due to small difference of the $R_{f}$ values of $\mathbf{2 7}$ and 28, their separation was successful at small scale only (ca $2 \mathrm{~g}$ of mixture per run). The 1,2;5,6-di-O-isopropylidene- $\alpha$-L-glucofuranose $\mathbf{2 7}$ was then subjected to the oxidation/reduction ( $\mathrm{a}$. $\mathrm{CrO}_{3}-\mathrm{Py}_{-} \mathrm{Ac}_{2} \mathrm{O} ;{ }^{34} \mathrm{~b}$. $\mathrm{NaBH}_{4}$ ) sequence to invert the configuration at the $\mathrm{C} 3$ position to produce the L-allose 29 which in turn was subjected to dehomologation $\left(\mathrm{a} . \mathrm{H}_{5} \mathrm{IO}_{6}, \mathrm{~b} . \mathrm{NaBH}_{4}{ }^{36,37}\right.$ ) at a $1 \mathrm{~g}$ scale which furnished the 1,2-O-isopropylidene- $\alpha$-L-ribofuranose 32 in a cumulative $69 \%$ yield (29 $\rightarrow$ 32). As mentioned above for the D-enantiomer this process did not function well at elevated scale. Considering the overall length of this process, difficulties during the separation of $\mathbf{2 7}$ and $\mathbf{2 8}$, and the low overall yield of the 1,2-O-isopropylidene- $\alpha$-L-ribofuranose 32 , a more efficient route was devised using L-xylose. 

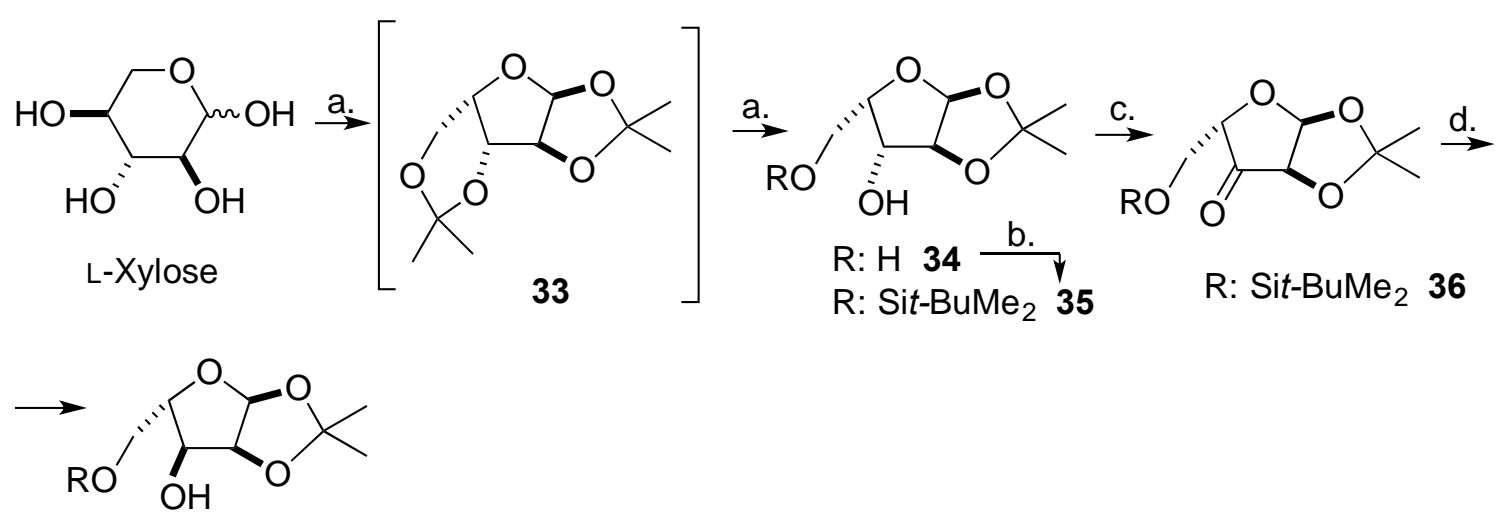

R: Sit-BuMe 237
R: H $32 \longleftarrow$ e.

Conditions: a. acetone, $\mathrm{H}_{2} \mathrm{SO}_{4}$ followed by $\mathrm{Na}_{2} \mathrm{CO}_{3}, \mathrm{H}_{2} \mathrm{O}$, one pot, $74 \%$; b. $t$ - $\mathrm{BuMe} \mathrm{SiCl}_{2}$, imidazole, $90 \%$; c. $\mathrm{CrO}_{3}, \mathrm{Py}, \mathrm{Ac}_{2} \mathrm{O}$; d $. \mathrm{NaBH}_{4}, 75.6 \%$, two steps; e. $\mathrm{Bu}_{4} \mathrm{NF} 89 \%$.

Scheme 3. Alternative access to L-ribose 32 via L-xylose.

This commercially available pentose was transformed in one pot ${ }^{70}$ [a. acetone, $\mathrm{H}_{2} \mathrm{SO}_{4}$; b. partial neutralization with $\mathrm{Na}_{2} \mathrm{CO}_{3}, \mathrm{H}_{2} \mathrm{O}$ ] to the 1,2-O-isopropylidene- $\alpha$-L-xylose. Selective protection of the primary $\mathrm{OH}$ group via silylation ( $t$-BuMe${ }_{2} \mathrm{SiCl}$, imidazole; $t-\mathrm{BuPh}_{2} \mathrm{Si}^{71}$ and $\mathrm{Tr}_{-}{ }^{72}$ were published for the same purpose) was nearly quantitative $(\mathbf{3 4} \rightarrow \mathbf{3 5})$. The compound 35 was subjected to inversion of configuration at the $\mathrm{C} 3$ position via oxidation-reduction (a. $\mathrm{CrO}_{3}-\mathrm{Py}_{-} \mathrm{Ac}_{2} \mathrm{O} ;{ }^{34} \mathrm{~b}$. $\mathrm{NaBH}_{4}$ ) followed by desilylation to furnish the 1,2-Oisopropylidene- $\alpha$-L-ribofuranose $\mathbf{3 2}$ with a total selectivity and good yield. Compound $\mathbf{3 2}$ is the L enantiomer of the intermediate $D$ 12, and can be further elaborated to obtain the $L$ 5-methyluridine 5 .

\section{Conclusions}

In conclusion, a larger laboratory scale route to obtain 5-methyluridine $\mathbf{1}$ is described using D-glucose as a precursor of the pivotal 1,2-O-isopropylidene- $\alpha$-D-ribofuranose 12. Its enantiomer L 32 was obtained starting from either L-arabinose via L-glucose and L-allose, or (much better) from L-xylose.

\section{Experimental Section}

General. EtOAc was dried by azeotropic removal of water; ca. $20 \%$ of a forerun was rejected and the rest was distilled. Acetone and $\mathrm{CH}_{2} \mathrm{Cl}_{2}$ were dried by shaking with $\mathrm{P}_{2} \mathrm{O}_{5}$ during 20 min, rapid filtration and distillation. DMF was dried by azeotropic removal of water using benzene or toluene (ca. $20 \%$ of the volume of DMF). Pyridine was dried by storage over $\mathrm{KOH}$. $\mathrm{MeOH}$ was dried by $\mathrm{Mg} / \mathrm{I}_{2}$ method. The ${ }^{1} \mathrm{H}$ and ${ }^{13} \mathrm{C}$ spectra were obtained on the Varian $300 \mathrm{MHz}$ spectrometer unless otherwise stated. Exact mass measurements were obtained on the Waters Xevo G2-XS QTof spectrometer. Optical rotations were measured on the Jasco P-2000 241 automatic polarimeter at ca $26{ }^{\circ} \mathrm{C}$. Moisture-sensitive reactions were performed using protecting atmosphere of argon dried by passage through "blue silica gel". Evaporations of the solvents were performed at ca $40{ }^{\circ} \mathrm{C} . \mathrm{MgSO}_{4}$ was used to dry the extracts. Column chromatography was performed using silica gel 70 - 
230 mesh from the Fluka. TLC chromatography was performed on the $0.2 \mathrm{~mm}$ silica gel aluminum plates (Fluka) and the spots were reveled using $10 \% \mathrm{H}_{2} \mathrm{SO}_{4}$ in $\mathrm{MeOH}$ and heating at ca. $110^{\circ} \mathrm{C}$.

1,2;5,6-Di-O-isopropylidene- $\alpha$-D-allofuranose 9. A round-bottom flask equipped with a reflux condenser and magnetic stirring bar was charged with $\mathrm{CH}_{2} \mathrm{Cl}_{2} 700(\mathrm{~mL})$ and $\mathrm{CrO}_{3}(60 \mathrm{~g}, 600 \mathrm{mmol})$. The flask was immersed in ice-water, and pyridine $(97 \mathrm{~mL}, 1200 \mathrm{mmol}$ ) was added portion wise during $10 \mathrm{~min}$. The cooling bath was removed. After stirring for $1 \mathrm{~h}$ at $\mathrm{rt}$, the dark brown mixture was cooled again with ice-water bath and 7 (39.3 $\mathrm{g}, 151 \mathrm{mmol}$ ) was added portionwise. After each addition of 7 a small volume of $\mathrm{Ac}_{2} \mathrm{O}$ was added. The total volume of $\mathrm{Ac}_{2} \mathrm{O}$ was $75 \mathrm{~mL}, 61.3 \mathrm{~g}, 600 \mathrm{mmol}$. After these intermittent additions which required $15 \mathrm{~min}$ the cooling bath was removed and oxidation continued for 25 min counting from the end of additions. TLC showed complete conversion of $7 \mathrm{R}_{\mathrm{f}} 0.49$ into more polar ulose $8 \mathrm{R}_{\mathrm{f}} 0.33$ (hexane - EtOAc 1:1). Most of $\mathrm{CH}_{2} \mathrm{Cl}_{2} \mathrm{Was}$ evaporated below $40{ }^{\circ} \mathrm{C}$ and $1: 1$ mixture of toluene - EtOAc, $(500 \mathrm{~mL})$ was added. This resulted in precipitation of insoluble black tar. The supernatant was decanted and the solid residue was washed twice with the same solvent. The combined solutions were passed through a short silica gel column prepared in toluene - EtOAc 1:2 using over pressure. The column was eluted with the same solvent system and product-containing fractions were evaporated. Xylenes $(100 \mathrm{~mL})$ were added and evaporation was continued to expel all residual pyridine. The oil obtained was dissolved in $96 \% \mathrm{EtOH}(300 \mathrm{~mL})$, cooled in ice-water bath and $\mathrm{NaBH}_{4}(5 \mathrm{~g}, 132 \mathrm{mmol})$ was added portionwise while maintaining magnetic stirring. The cooling bath was removed and stirring was continued overnight. TLC showed allose $9 \mathrm{R}_{\mathrm{f}} 0.36$ slightly less polar than the ulose 8 (hexane - EtOAc 1:1). Acetone $(10 \mathrm{~mL})$ was added to destroy the excess of $\mathrm{NaBH}_{4}$ and most of the volatiles were evaporated. The residue was taken up in $\mathrm{CH}_{2} \mathrm{Cl}_{2}$ and washed with water. The organic phase was dried $\left(\mathrm{MgSO}_{4}\right)$ and evaporated to yield solid crude 9 (31.1 g, 79\% for two steps). Mp $72-75^{\circ} \mathrm{C}$ (hexane - EtOH), $[\alpha]_{\mathrm{D}}{ }^{26}+36.7$ (c $\left.2 \mathrm{CHCl}_{3}\right)$; lit. ${ }^{32}$ $\mathrm{mp} 74-75^{\circ} \mathrm{C}$ (toluene), $[\alpha]_{\mathrm{D}}+38.8\left(\mathrm{c} 1.03 \mathrm{CHCl}_{3}\right.$ ). NMR: see L-enantiomer 29.

\section{1,2-O-Isopropylidene- $\alpha$-D-ribofuranose 12}

A. Via $\mathrm{H}_{5} \mathrm{IO}_{6} / \mathrm{NaBH}_{4}$. Compound 9 (27 g, $\left.103.8 \mathrm{mmol}\right)$ was dissolved in dry EtOAc $(150 \mathrm{~mL})$ and stirred with $\mathrm{H}_{5} \mathrm{O}_{6}(99 \%$ pure, $28.7 \mathrm{~g}, 124.6 \mathrm{mmol}$ ) added in three portions. A white precipitate soon appeared. TLC showed the aldehyde $11 \mathrm{Rf} 0.29$ (hexane - EtOAc 1:2); the substrate 9 has $R_{f} 0.36$ (hexane - EtOAc 1:1). After $2 \mathrm{~h}$ filtration was performed using a sintered glass and the precipitate was washed with EtOAc. The volatiles were removed by evaporation. Some solid material appeared. EtOAc $(50 \mathrm{~mL})$ was added and filtration/evaporation was repeated. The residual oil was briefly dried on an oil pump, dissolved in $96 \% \mathrm{EtOH}(100 \mathrm{~mL})$, cooled in icewater bath and treated with $\mathrm{NaBH}_{4}(5 \mathrm{~g}, 132 \mathrm{mmol})$. The cooling bath was removed. $\mathrm{R}_{\mathrm{f}}$ of the product 12 was 0.46 in $\mathrm{CH}_{2} \mathrm{Cl}_{2}-\mathrm{MeOH}$ 20:1.5. After $3 \mathrm{~h}$ most of EtOH was evaporated and the residue was dissolved in $\mathrm{CH}_{2} \mathrm{Cl}_{2}$ and this solution was washed with water. The water phase was back extracted twice with $\mathrm{CH}_{2} \mathrm{Cl}_{2}$. The combined organic phases were dried, filtered and evaporated. Purification by chromatography $\mathrm{CH}_{2} \mathrm{Cl}_{2}-\mathrm{MeOH}$ $20: 1.4$ furnished 12 (4.9 g, 25\%).

B. Via stepwise hydrolysis and $\mathrm{NaIO}_{4} / \mathrm{NaBH}_{4}$ treatment. To a cold (ice bath) solution of $\mathbf{9}$ (35 g, $134.6 \mathrm{mmol}$ ) in $\mathrm{MeOH}(300 \mathrm{~mL})$ was added cold $0.8 \% \mathrm{H}_{2} \mathrm{SO}_{4}(250 \mathrm{~mL})$, and the mixture was left overnight at rt. TLC showed that $9\left(R_{f} 0.36\right.$ in hexane - EtOAc 1:1) reacted to form $10 R_{f} \sim 0$ in the same solvent system, or $R_{f} 0.21$ in $C_{2} C l_{2}-$ $\mathrm{MeOH}$ 9:1. Amberlite IRA $410\left(\mathrm{OH}^{-}\right)$was added to neutralize the acid and was removed by filtration and washed with $\mathrm{MeOH}$. The volatiles were removed by evaporation to yield crude 10 as a syrup. A small amount of this material was purified by chromatography using $\mathrm{CH}_{2} \mathrm{Cl}_{2}-\mathrm{MeOH}$ 9:1 to get the crystalline material, mp $130-134{ }^{\circ} \mathrm{C}$ (EtOAc - EtOH); lit. ${ }^{32} \mathrm{mp} .131-133{ }^{\circ} \mathrm{C}\left(\mathrm{Et}_{2} \mathrm{O}-\mathrm{MeOH}\right)$ The bulk of the crude product was dissolved in $96 \% \mathrm{EtOH}(250 \mathrm{~mL})$ and treated with a suspension of $\mathrm{NalO}_{4}(30 \mathrm{~g}, 140 \mathrm{mmol})$, in $\mathrm{H}_{2} \mathrm{O}(100 \mathrm{~mL})$ with magnetic stirring. A white precipitate started to deposit immediately. After $4 \mathrm{~h}$ TLC showed a conversion of 10 into the 
aldehyde $11 R_{f} 0.29$ in hexane - EtOAc 1:2. The whole mixture was filtered on a sintered glass and the solid material was washed with $\mathrm{EtOH}$. $\mathrm{NaBH}_{4}(6 \mathrm{~g}, 158.7 \mathrm{mmol}$ ) was added to the cold (ice bath) filtrate and the mixture was stirred magnetically during $5 \mathrm{~h}$ at $\mathrm{rt}$. The work-up and purification as described above furnished 12 (16.9 g, 76\% for three steps). 12: $\mathrm{mp} 85^{\circ} \mathrm{C}$ (hexane - EtOAC), $[\alpha]_{\mathrm{D}}{ }^{26}+69$ (c 2.2, EtOH); lit. ${ }^{73} 85.5-86{ }^{\circ} \mathrm{C},[\alpha]_{\mathrm{D}}+$ 65 (c $1.0 \mathrm{EtOH}$ ). NMR: see L enantiomer 32.

1-O-Acetyl 2,3,5-tri-O-benzoyl- $\boldsymbol{\beta}$-D-ribofuranose 15. The conversion of 12 into 15 was performed without isolation of the intermediates. The acetonide $12(25 \mathrm{~g}, 132 \mathrm{mmol})$ in $70 \% \mathrm{AcOH}(150 \mathrm{~mL})$ was maintained at 80 ${ }^{\circ} \mathrm{C}$ during $3 \mathrm{~h}$, whereupon the volatiles were removed by evaporation below $40{ }^{\circ} \mathrm{C}$. Coevaporation with xylenes and drying on an oil pump furnished glassy material, which was dissolved in dry $\mathrm{MeOH}(400 \mathrm{~mL})$ and the mixture was cooled down in ice bath and magnetically stirred. $\mathrm{H}_{2} \mathrm{SO}_{4}(97 \%, 2 \mathrm{~mL}$ ) was added slowly and the mixture was left for $18 \mathrm{~h}$ in a refrigerator. Saturated aq $\mathrm{Ba}(\mathrm{OH})_{2}$ was added to neutrality and precipitated $\mathrm{BaSO}_{4}$ was removed by filtration through Celite. The volatiles were removed on an evaporator and on an oil pump. To the residue was added pyridine $(300 \mathrm{~mL})$, followed by $\mathrm{BzCl}(54 \mathrm{~mL}, 64.6 \mathrm{~g}, 460 \mathrm{mmol})$, added dropwise under magnetic stirring and with cooling in an ice bath and under a blanket of argon. After an overnight reaction, $\mathrm{TLC}\left(\mathrm{CHCl}_{3}-\mathrm{MeOH} 9: 1\right)$ showed two products having $\mathrm{R}_{\mathrm{f}} 0.68$ and 0.80 , presumably both anomeric compounds 14 . Water $(5 \mathrm{~mL})$ was added to hydrolyze the excess of $\mathrm{BzCl}$ and $2 \mathrm{~h}$ later an extraction was performed $\left(\mathrm{CH}_{2} \mathrm{Cl}_{2}\right.$ - ice $\left.-5 \mathrm{~N} \mathrm{HCl}\right)$. The organic phase was washed with aq $\mathrm{Na}_{2} \mathrm{CO}_{3}$, water $(2 \mathrm{x})$, dried and evaporated. To the residue $(58 \mathrm{~g})$ was added $\mathrm{AcOH}(40 \mathrm{~mL})$ and $\mathrm{Ac}_{2} \mathrm{O}(90 \mathrm{~mL})$. The solution was chilled in an ice - salt bath and conc. $\mathrm{H}_{2} \mathrm{SO}_{4}(14 \mathrm{~mL})$ was added dropwise under a blanket of argon and with manual swirling. The flask was closed with a rubber septum and left at ca. $-5^{\circ} \mathrm{C}$ for $10 \mathrm{~h}$. TLC showed the compound $15 \mathrm{R}_{\mathrm{f}} 0.60$ (hexane - EtOAc, 2:1) together with less and more polar byproducts. $\mathrm{CH}_{2} \mathrm{Cl}_{2}$ was added and the solution was transferred to a separatory funnel charged with ice and water and extraction was performed. The organic layer was washed with water $(3 \mathrm{x})$, dried and evaporated. Addition of $i$-PrOH resulted in spontaneous crystallization. Filtration, washing with cold $i$-PrOH and prolonged drying on an oil pump furnished 15 (29.8 g, $45 \%$ cumulative yield), which was the best yield obtained.

$\mathrm{mp} 130-133{ }^{\circ} \mathrm{C}$ (i-PrOH), $[\alpha]_{\mathrm{D}}{ }^{26}+43.1$ (c 2, $\mathrm{CHCl}_{3}$ ); lit. ${ }^{5} 131-132{ }^{\circ} \mathrm{C},[\alpha]_{\mathrm{D}}+45.1$ (c $\left.1.32 \mathrm{CHCl}_{3}\right) .{ }^{1} \mathrm{H}\left(\mathrm{CDCl}_{3}\right): 8.01-$ $7.32(15 \mathrm{H}), 6.44(1 \mathrm{H}, s), 5.91(1 \mathrm{H}, \mathrm{dd}, J 5.0 \mathrm{~Hz}$ and $6.4 \mathrm{~Hz}), 5.79(1 \mathrm{H}, \mathrm{d}, J 4.8 \mathrm{~Hz}), 4.82-4.75(2 \mathrm{H}$, unresolved), $4.52(1 \mathrm{H}, \mathrm{dd}, J 5.7 \mathrm{~Hz}$ and $13.9 \mathrm{~Hz}), 2.00(3 \mathrm{H}, \mathrm{s}) .{ }^{13} \mathrm{C}\left(\mathrm{CDCl}_{3}\right): 169.2,166.1,165.5,165.2,133.8,133.7,133.4$, $130.0,129.9,128.7,128.6,98.6,80.2,75.2,71.6,63.9,21.0$.

\section{5-Methyluridine 1}

A. via 2,3,5-tri-O-benzoyl-5-methyluridine 17. Thymine (35.9 g, $297 \mathrm{mmol}), \mathrm{HMDS}(400 \mathrm{~mL})$ and $\left(\mathrm{NH}_{4}\right)_{2} \mathrm{SO}_{4}$ $(0.5 \mathrm{~g})$ were refluxed under argon until a clear solution was obtained (ca. $4 \mathrm{~h}$ ). Excess of the reagent was evaporated. Co-evaporation with toluene was performed followed by drying on an oil pump. $\mathrm{CH}_{3} \mathrm{CN}(700 \mathrm{~mL})$ was added, followed by 15 (145 g, $288 \mathrm{mmol}$ ). The flask was immersed in ice-water bath and $\mathrm{SnCl}_{4}$ (76 mL, 167 $\mathrm{g}, 649 \mathrm{mmol}$ ) was added using a syringe while maintaining magnetic stirring. After $1 \mathrm{~h}$ counting from the end of addition, the cooling bath was removed and the reaction proceeded at rt. After a total time of $6 \mathrm{~h}$ TLC showed that all 15 had reacted to form a more polar product $17\left(R_{f} 0.85\right.$ and 0.31 , respectively, in hexaneEtOAc, 2:1). The mixture was transferred to a separatory funnel charged with $\mathrm{CH}_{2} \mathrm{Cl}_{2}(700 \mathrm{~mL})$ and ice-cold water (4 L), and extraction was performed. The organic layer was washed again with water, dried and the volatiles were evaporated. The hard crystalline mass thus obtained weighed $182 \mathrm{~g}$. A small amount crude 17 was purified by chromatography in hexane-EtOAc, 2:1 to get an analytical sample. The abovementioned mass was dissolved in 1,4-dioxane $(200 \mathrm{~mL})$ with warming, and $\mathrm{MeOH}(600 \mathrm{~mL})$ was added followed by few pieces of sodium and the mixture was left over the weekend. Amberlite IRA $120 \mathrm{H}^{+}$was added to remove the $\mathrm{Na}$ cations, and was filtered off and washed with $\mathrm{MeOH}$. Most of the volatiles were evaporated to a point that the 
crystallization did not start. Water was added followed by $\mathrm{CHCl}_{3}$ and extraction was performed three times to remove methyl benzoate. The water phase was evaporated until turbidity and was incubated in a refrigerator for $24 \mathrm{~h}$. To the resulting semi-crystalline mass was added small volume of cold $96 \% \mathrm{EtOH}$. The crystals were removed by filtration, washed twice with cold $96 \% \mathrm{EtOH}$ and with $\mathrm{Et}_{2} \mathrm{O}$. Final drying on oil pump gave 1 (67 $\mathrm{g}$, ca. $90 \%$ for two steps). 17: $\mathrm{mp} 161-164{ }^{\circ} \mathrm{C}(\mathrm{EtOH})$; lit. ${ }^{48} \mathrm{mp} 163-164{ }^{\circ} \mathrm{C}$. Exact mass: calc. for $\left[\mathrm{C}_{31} \mathrm{H}_{11} \mathrm{~N}_{2} \mathrm{O}_{9}+\right.$ $\mathrm{Na}]^{+}=593.1531$, found: $593.1523 .{ }^{1} \mathrm{H}\left(\mathrm{CDCl}_{3}\right): 9.59(1 \mathrm{H}$, exchangeable), 8.14-7.34 (15H, four groups of signals), $7.17(1 \mathrm{H}$, unresolved q, J 1Hz), $6.43(1 \mathrm{H}, \mathrm{d}, J 6 \mathrm{~Hz}), 5.92(1 \mathrm{H}, \mathrm{dd}, J 3 \mathrm{~Hz}$ and $6 \mathrm{~Hz}), 5.77(1 \mathrm{H}, \mathrm{t}, J 6 \mathrm{~Hz}), 4.87(1 \mathrm{H}$, $\mathrm{dd}, J 3 \mathrm{~Hz}$ and $12 \mathrm{~Hz}), 4.71-4.66\left(1 \mathrm{H}\right.$, unresolved), $4.63(1 \mathrm{H}, \mathrm{d}, J 6 \mathrm{~Hz}), 1.58(3 \mathrm{H}$, unresolved d, J $1 \mathrm{~Hz}) .{ }^{13} \mathrm{C}$ $\left(\mathrm{CDCl}_{3}\right): 165.9,165.3,163.7,150.4,134.9,133.7,133.6,133.5,129.8,129.7,129.5,129.1,128.7,128.5,128.4$, $112.1,86.9,80.4,73.3,71.3,63.9,12.0$.

1: $\mathrm{mp} 180-182{ }^{\circ} \mathrm{C}(96 \% \mathrm{EtOH}),[\alpha]_{\mathrm{D}}^{26}-8.9$ (c 1.9, $\mathrm{H}_{2} \mathrm{O}$ ); lit. ${ }^{48} 182-184{ }^{\circ} \mathrm{C}$, lit. ${ }^{74}[\alpha]_{\mathrm{D}}+4.5$ (c $1 \mathrm{H}_{2} \mathrm{O}$ ) for the $\mathrm{L} 5-$ methyluridine. ${ }^{1} \mathrm{H}\left(\mathrm{D}_{2} \mathrm{O}\right): 7.61(1 \mathrm{H}$, unresolved d, J $1 \mathrm{~Hz}), 5.81(1 \mathrm{H}, \mathrm{d}, J 4.5 \mathrm{~Hz}, 4.25(1 \mathrm{H}, \mathrm{t}, J 5.1 \mathrm{~Hz}), 4.15(1 \mathrm{H}, \mathrm{t}, J$ $5.2 \mathrm{~Hz}$ ), 4.09-4.00 (1H, unresolved), $3.84(1 \mathrm{H}, \mathrm{dd}, J 3 \mathrm{~Hz}$ and J 12.5), $3.73(1 \mathrm{H}, \mathrm{dd}, J 4.2$ and $12.9 \mathrm{~Hz}), 1.80(3 \mathrm{H}$, s). ${ }^{1} \mathrm{H}$ (DMSO- $\left.d_{6}\right): 11.30$ (bs, exchangeable). ${ }^{13} \mathrm{C}\left(\mathrm{D}_{2} \mathrm{O}\right): 166.6,151.9,137.5,111.6,89.2,84.3,73.7,69.5,60.8$, 11.7.

B. Via 2,3,5-tri-O-acetyl-5-methyluridine 18. Thymine $(8.63 \mathrm{~g}, 77 \mathrm{mmol})$, hexamethyldisilazane $(100 \mathrm{~mL})$ and $\left(\mathrm{NH}_{4}\right)_{2} \mathrm{SO}_{4}(0.1 \mathrm{~g})$ were refluxed under argon until the solution became clear (ca. $\left.3 \mathrm{~h}\right)$. Excess of the HMDS was removed by evaporation and the oily residue was dried on an oil pump. Vacuums were broken using balloons with argon. To the residue was added $\mathrm{CH}_{3} \mathrm{CN}(400 \mathrm{~mL}$ ), followed by 16 (98\% pure, $25 \mathrm{~g}, 77 \mathrm{mmol})$ and $\mathrm{SnCl}_{4}$ $(19.9 \mathrm{~mL}, 169 \mathrm{mmol})$ added via a syringe. The mixture was stirred magnetically during $11 \mathrm{~h}$. TLC showed that 16 was consumed and more polar 18 was formed $\left(R_{f} 0.65\right.$ and 0.18 , respectively, in hexane-EtOAc, 1:1). Most of $\mathrm{CH}_{3} \mathrm{CN}$ was evaporated below $30{ }^{\circ} \mathrm{C}$ and the residue was transferred to a separatory funnel charged with $\mathrm{CH}_{2} \mathrm{Cl}_{2}$ and ice cold water, and extraction was performed. The organic layer was washed with water, dried and the volatiles were evaporated to give a sticky oil. A small amount of this material was purified by chromatography in hexane-EtOAc, 1:1 to get a sample for analysis. The bulk of the crude extract was dissolved in 1,4-dioxane $(50 \mathrm{~mL})$ and $\mathrm{MeOH}(300 \mathrm{~mL})$. A piece of $\mathrm{Na}$ was added and the mixture was left overnight. Amberlite IRA $120 \mathrm{H}^{+}$was added and 15 min later was removed by filtration on sintered glass and washed with $\mathrm{MeOH}$. Evaporation of the volatiles was conducted until spontaneous crystallization started. The flask was left in a refrigerator overnight. To a semi-solid mass was added cold $96 \% \mathrm{EtOH}$ and the crystals were filtered off, washed with cold $96 \% \mathrm{EtOH}$ and finally with $\mathrm{Et}_{2} \mathrm{O}$. Drying on oil pump furnished 1 (14.1 g, 69.5\% for two steps). 18: syrup; $[\alpha]_{D}{ }^{26}-10.5$ (c $1, \mathrm{CH}_{2} \mathrm{Cl}_{2}$ ), lit. ${ }^{75}[\alpha]_{\mathrm{D}}-14.6$ (c $\left.0.40 \mathrm{EtOH}\right) .{ }^{1} \mathrm{H}(400 \mathrm{MHz}, \mathrm{CDCl} 3): 9.45$ (1H, bs, exchangeable), $7.17(1 \mathrm{H}, \mathrm{bs}), 6.05(1 \mathrm{H}$, apparent $\mathrm{d}), 5.32(2 \mathrm{H}$, apparent $\mathrm{d}, \mathrm{J} 4 \mathrm{~Hz}), 4.34-4.30$ (3H, unresolved), 2.13, 2.10, 2.07 three $\mathrm{s}, 3 \mathrm{H}$ each, $1.91(3 \mathrm{H}$, unresolved $\mathrm{d}, J 1 \mathrm{~Hz}) .{ }^{13} \mathrm{C}\left(100 \mathrm{MHz}^{\mathrm{C}} \mathrm{CDCl}_{3}\right): 170.1,169.7,163.6$, $150.5,134.9,111.9,86.9,79.8,72.5,70.3,63.2,20.7,20.5,20.4,12.6$.

\section{1,2;5,6-Di-O-isopropylidene- $\alpha$-L-glucofuranose 27 and 2,3;5,6-di-O-isopropylidene-L-mannofuranose 28 via} 1-deoxy-1-nitro-L-glucitol 21 and 1-deoxy-1-nitro-L-mannitol 22. To a solution of NaOMe prepared from $\mathrm{Na}$ $(3.7 \mathrm{~g}, 0.16 \mathrm{~mol})$ and $\mathrm{MeOH}(200 \mathrm{~mL})$ was added $\mathrm{CH}_{3} \mathrm{NO}_{2}(60 \mathrm{~mL}, 68.2 \mathrm{~g}, 1.1 \mathrm{~mol})$ and L-arabinose $(15 \mathrm{~g}, 0.1$ mol). The whole was stirred magnetically under a protecting atmosphere of dry argon during $18 \mathrm{~h}$. The precipitated sodium salts of the nitroglucitol and nitromannitol were filtered off, washed with cold $\mathrm{MeOH}$, dissolved in cold (ca. $5^{\circ} \mathrm{C}$ ) water $100 \mathrm{~mL}$, and this solution was added dropwise during 10 min to a solution of conc. $\mathrm{H}_{2} \mathrm{SO}_{4}(20 \mathrm{~mL})$ in water $(25 \mathrm{~mL})$ at rt. $5 \mathrm{~min}$ after the end of addition, neutralization was performed using a warm (ca. $45^{\circ} \mathrm{C}$ ) solution of $\mathrm{Ba}(\mathrm{OH})_{2}$. Precipitated $\mathrm{BaSO}_{4}$ was removed by filtration through a bed of Celite. The filtrate as demineralized through passage through a column of $200 \mathrm{~mL}$ of the Amberlite IRA $120 \mathrm{H}^{+}$ followed by the Amberlite IRA $410 \mathrm{OH}^{-}$. The resins were washed with water $(2 \times 100 \mathrm{~mL})$. The combined 
aqueous solutions were evaporated and the glassy residue obtained was dried on oil pump overnight. Acetone $(250 \mathrm{~mL})$ was added followed by conc. $\mathrm{H}_{2} \mathrm{SO}_{4}(7 \mathrm{~mL})$ and the mixture was subjected to ultrasound ${ }^{67}$ in a domdesstic cleansing bath for $50 \mathrm{~min}$. This was performed in round-bottom flask even though it was recommended to use flat-bottom flasks due to smaller dispersion of the ultrasound. TLC showed the L-manno compound $28 R_{f} 0.46$ and more polar L-gluco compound $27 R_{f} 0.40$ (in hexane-EtOAc, 2:1). The reaction mixture was neutralized with cold conc. $\mathrm{NH}_{4} \mathrm{OH}$ and precipitated $\left(\mathrm{NH}_{4}\right)_{2} \mathrm{SO}_{4}$ was removed by filtration through Celite. The solids were washed with acetone and the combined brownish solutions were evaporated to leave material ( $2 \mathrm{~g}$ ) which was separated using vacuum-dry chromatography ${ }^{68,69}$ (in hexane-EtOAc, 2:1) to yield less polar $28(0.75 \mathrm{~g})$ and more polar $27(0.43 \mathrm{~g})$. Due to the presence of impurities, no effort was made to isolate 1,2-O-isopropylidene-L-glucofuranose invariably present during acetonation of glucose.

27: $\mathrm{mp} 103-106{ }^{\circ} \mathrm{C}$ (hexane - EtOAc), $[\alpha]_{\mathrm{D}}{ }^{26}+17.5$ (c 2, acetone); lit. ${ }^{67} 105-106^{\circ} \mathrm{C},[\alpha]_{\mathrm{D}}-18.7$ (c not mentioned, acetone) for the $D$ enantiomer. ${ }^{1} \mathrm{H}\left(400 \mathrm{MHz}_{\mathrm{CDCl}}\right): 5.94(1 \mathrm{H}, \mathrm{d}, J 4.0 \mathrm{~Hz}), 4.53(1 \mathrm{H}, \mathrm{d}, J 3.5 \mathrm{~Hz}), 4.37-4.31(2 \mathrm{H}$, unresolved), $4.16(1 \mathrm{H}, \mathrm{dd}, J 6.5 \mathrm{~Hz}$ and $8.8 \mathrm{~Hz}), 4.07(1 \mathrm{H}, \mathrm{dd}, J 2.8 \mathrm{~Hz}$ and $7.8 \mathrm{~Hz}), 4.00(1 \mathrm{H}, \mathrm{dd}, J 5.4 \mathrm{~Hz}$ and 8.8 $\mathrm{Hz}), 2.70(1 \mathrm{H}$, exchangeable, $\mathrm{d}, J 3.7 \mathrm{~Hz}), 1.68,1.62,1.53,1.48$ four $\mathrm{s}, 3 \mathrm{H}$ each. ${ }^{13} \mathrm{C}\left(100 \mathrm{MHz}, \mathrm{CDCl}_{3}\right): 111.6$, $109.3,105.0,85.0,81.1,74.5,72.8,67.4,26.6,26.0,25.0$.

28: $\mathrm{mp} 120-124{ }^{\circ} \mathrm{C}$ (hexane - EtOAc), $[\alpha]_{\mathrm{D}}^{26}-14.0$ (c 2, EtOH); lit. ${ }^{76} 121.5-122.5,[\alpha]_{\mathrm{D}}-15.7$ (c $\left.2.5 \mathrm{EtOH}\right)$.

${ }^{1} \mathrm{H}\left(\mathrm{CDCl}_{3}\right): 5.73$ (s, residual water), $4.80(1 \mathrm{H}, \mathrm{dd}, J 3.7 \mathrm{~Hz}$ and $5.9 \mathrm{~Hz}), 4.61(1 \mathrm{H}, \mathrm{d}, J 5.9 \mathrm{~Hz}), 4.44-4.38(2 \mathrm{H}, \mathrm{m})$, $4.18(1 \mathrm{H}, \mathrm{dd}, J 3.6 \mathrm{~Hz}$ and $7.1 \mathrm{~Hz}), 4.08(1 \mathrm{H}, \mathrm{dd}, J 5.9 \mathrm{~Hz}$ and $8.7 \mathrm{~Hz}), 4.05(1 \mathrm{H}, \mathrm{dd}, J 5.0 \mathrm{~Hz}$ and $8.7 \mathrm{~Hz}), 3.27(1 \mathrm{H}$, exchangeable, $J 2.5 \mathrm{~Hz}), 1.47,1.46,1.36,1.32$ four $\mathrm{s}, 3 \mathrm{H}$ each. ${ }^{13} \mathrm{C}\left(\mathrm{CDCl}_{3}\right) 112.6,109.1,101.2,85.4,80.1,79.6$, 73.2, 66.5, 26.8, 25.8, 25.1, 24.4 .

1,2;5,6-Di-O-isopropylidene- $\alpha$-L-allofuranose 29 . Following the directions described for the $\mathrm{D}$ enantiomer, 7 and proportional quantities of the reagents, $27(2.1 \mathrm{~g})$ furnished $29(1.45 \mathrm{~g}, 69 \%)$. Mp $74-77^{\circ} \mathrm{C}$ (hexane EtOAc), $[\alpha]_{D}{ }^{26}-34.5$ (c $2 \mathrm{CHCl}_{3}$ ), lit. ${ }^{32} \mathrm{mp} .78-79^{\circ} \mathrm{C},[\alpha]_{\mathrm{D}}-36.2$ (c $0.5 \mathrm{CHCl}_{3}$ ). Exact mass: calc. for $\left[\mathrm{C}_{12} \mathrm{H}_{20} \mathrm{O}_{6}\right]^{+}=$ 260.1259, found: 260.1254 ; calc. for $\left[\mathrm{C}_{12} \mathrm{H}_{20} \mathrm{O}_{6}+\mathrm{Na}\right]^{+}=283.1152$, found: $283.1149 .{ }^{1} \mathrm{H}\left(400 \mathrm{MHz}, \mathrm{CDCl}_{3}\right): 5.81$ $(1 \mathrm{H}, \mathrm{d}, J 4.0 \mathrm{~Hz}), 4.62(1 \mathrm{H}, \mathrm{dd}, J 4.0 \mathrm{~Hz}$ and $5.0 \mathrm{~Hz}), 4.32(1 \mathrm{H}, \mathrm{dt}, J 5.0 \mathrm{~Hz}$ and $6.0 \mathrm{~Hz}$ and $6.0 \mathrm{~Hz}), 4.11-4.00(3 \mathrm{H}$, m), $3.83(1 \mathrm{H}, \mathrm{dd} J 5.0 \mathrm{~Hz}$ and $8.5 \mathrm{~Hz}), 2.63(1 \mathrm{H}$, exchangeable, J 9.0 Hz), 1.60, 1.48, 1.40, $1.38 \mathrm{four} s, 3 \mathrm{H}$ each. ${ }^{13} \mathrm{C}\left(100 \mathrm{MHz}_{\mathrm{CDCl}}\right):$ : 112.7, 109.7, 103.8, 79.6, 78.9, 75.5, 72.4, 65.7 26.5, 26.4, 26.2, 25.2.

\section{1,2-O-Isopropylidene- $\alpha$-L-ribofuranose 32}

A. By degradation of 29. Following the directions described for the transformation of 9 into 12 using the Conditions B and proportional quantities of the reagents, L-allose 29 (1.1 g) was transformed into 32 (0.76 g, $69 \%)$ after chromatography in $\mathrm{CH}_{2} \mathrm{Cl}_{2}-\mathrm{MeOH}, 20: 1$.

B. By desilylation of $\mathbf{3 7}$. To a solution of $37(13.2 \mathrm{~g}, 38.8 \mathrm{mmol})$ in THF $(50 \mathrm{~mL})$ was added $1 \mathrm{M} \mathrm{Bu}_{4} \mathrm{NF}$ in THF $(41 \mathrm{~mL})$. After $3 \mathrm{~h}$, TLC showed that the substrate $37\left(R_{f} 0.51\right.$, hexane-EtOAc 4:1) had been consumed to form a product $32 \mathrm{R}_{\mathrm{f}} 0.41\left(\mathrm{CH}_{2} \mathrm{Cl}_{2}-\mathrm{MeOH} 20: 1\right)$. The solvent was evaporated and residual oil was purified by chromatography $\left(\mathrm{CH}_{2} \mathrm{Cl}_{2}-\mathrm{MeOH} 20: 1\right)$ to give 32 (7.3 g, 89\%). Mp 83-86 ${ }^{\circ} \mathrm{C}$ (hexane - EtOAC), $[\alpha]_{\mathrm{D}}{ }^{26}-42.0$ (c 2.2, $\mathrm{CH}_{2} \mathrm{Cl}_{2}$ ); lit. ${ }^{72} 84-86^{\circ} \mathrm{C}$, $[\alpha]_{\mathrm{D}}-45.3$ (c $1.00 \mathrm{CH}_{2} \mathrm{Cl}_{2}$ ). Exact mass: cal. for $\left[\mathrm{C}_{8} \mathrm{H}_{14} \mathrm{O}_{5}+\mathrm{Na}\right]^{+}=213.0733$, found: 213.0740. $\mathrm{NMR}^{1} \mathrm{H}\left(\mathrm{CDCl}_{3}\right): 5.81(1 \mathrm{H}, \mathrm{d}, J 3.7 \mathrm{~Hz}), 4.58(1 \mathrm{H}, \mathrm{t}, J 4.4 \mathrm{~Hz}), 4.02-3.96(2 \mathrm{H}, m), 3.84(1 \mathrm{H}, \mathrm{dt}, J 3.1 \mathrm{~Hz}$ and $3.1 \mathrm{~Hz}$ and $4.4 \mathrm{~Hz}), 3.74(1 \mathrm{H}, \mathrm{dd}, J 3.6 \mathrm{~Hz}$ and $12.2 \mathrm{~Hz}), 2.47(\mathrm{bs}), 1.57,1.373 \mathrm{H}$ each, two s. ${ }^{13} \mathrm{C}\left(\mathrm{CDCl}_{3}\right)$ : 112.7, 103.9, 80.6, 78.7, 70.8, 60.8, 26.5, 26.4 .

1,2-O-isopropilidene- $\alpha$-L-xylofuranose 34. To a magnetically stirred suspension of L-xylose (15 g, $100 \mathrm{mmol})$ in acetone $(400 \mathrm{~mL})$ was added dropwise conc. $\mathrm{H}_{2} \mathrm{SO}_{4}(15 \mathrm{~mL}, 27.6 \mathrm{~g}, 181 \mathrm{mmol})$ during $5 \mathrm{~min}$. After $30 \mathrm{~min}$ counting from the end of addition, the mixture was cooled in ice-water bath and a solution of $\mathrm{Na}_{2} \mathrm{CO}_{3}(20 \mathrm{~g}$, $189 \mathrm{mmol})$ in $\mathrm{H}_{2} \mathrm{O}(190 \mathrm{~mL})$ was slowly added while maintaining the internal temperature below $20^{\circ} \mathrm{C}$. After $2.5 \mathrm{~h}$ TLC showed nearly complete hydrolysis of the bis-acetonide $\mathbf{3 3} \mathrm{R}_{\mathrm{f}}$ ca 0.90 and formation of the diol $\mathbf{3 4} \mathrm{R}_{\mathrm{f}}$ 
$0.45\left(\mathrm{CH}_{2} \mathrm{Cl}_{2}-\mathrm{MeOH} 20: 1\right)$. More $\mathrm{Na}_{2} \mathrm{CO}_{3}(10 \mathrm{~g})$ was added to effect a complete neutralization. After stirring for $10 \mathrm{~min}$ the solid material was removed by filtration through sintered glass and was washed with acetone. Evaporation of acetone and chromatography in $\mathrm{CH}_{2} \mathrm{Cl}_{2}-\mathrm{MeOH}$ 20:1 furnished 34 (14 g, 74\%); mp 37-38 ${ }^{\circ} \mathrm{C}$; $[\alpha]_{D}{ }^{26}+17\left(c 3, \mathrm{CHCl}_{3}\right)$; lit. ${ }^{77}$ for the $\mathrm{D}$ enantiomer: oil, $[\alpha]_{D}-13.9\left(c 0.34 \mathrm{CHCl}_{3}\right)$. Alternative approach to get 34 was reported in the ref. 78. $\mathrm{NMR}^{1} \mathrm{H}\left(\mathrm{DMSO}_{-} \mathrm{d}_{6}\right): 5.79(1 \mathrm{H}, \mathrm{d}, J 3.7 \mathrm{~Hz}), 5.13$ (exchangeable, $\left.\mathrm{d}, J 4.7 \mathrm{~Hz}\right), 4.61$ (exchangeable, $\mathrm{t}, J 5.6 \mathrm{~Hz}$ ), 4.36 (exchangeable, $\mathrm{d}, J 3.7 \mathrm{~Hz}$ ), 4.00-3.92 (2H, unresolved), 3.64-3.57 (1H, m of five lines, J $5.6 \mathrm{~Hz}$ ), 3.54-3.46 (1H, m of five lines, J $5.6 \mathrm{~Hz}$ ), [after $\mathrm{D}_{2} \mathrm{O}$ exchange: $3.62(\mathrm{dd}, J 5.0 \mathrm{~Hz}$ and $11.2 \mathrm{~Hz}$; 3.50 (dd, $J 6.1 \mathrm{~Hz}$ and $11.2 \mathrm{~Hz}$ )], 1.38 and 1.23 (two s, $3 \mathrm{H}$ each). ${ }^{13} \mathrm{C}$ (DMSO-d (D) $_{1} 110.2,104.2,85.0,81.3,73.4$, $58.8,26.6,26.1$.

5-O-tButyldimethylsilyl-1,2-O-isopropylidene- $\alpha$-L-xylofuranose 35 . The title compound was obtained as an oil following the published procedure ${ }^{79}$ in higher yield, $90 \%$ vs. $75 \%$. $[\alpha]_{D}{ }^{26}+9.1$ (c 4, $\mathrm{CHCl}_{3}$ ); lit. ${ }^{79}[\alpha]_{\mathrm{D}}+11$ (c 5.4 $\left.\mathrm{CHCl}_{3}\right) .{ }^{1} \mathrm{H}\left(400 \mathrm{MHz}, \mathrm{CDCl}_{3}\right): 5.96(1 \mathrm{H}, \mathrm{d}, \mathrm{J} \sim 0.8 \mathrm{~Hz}), 4.50(1 \mathrm{H}, \mathrm{d}, J 4.0 \mathrm{~Hz}), 4.37$ and 4.33 (1H each, bs), 4.15$4.10\left(3 \mathrm{H}\right.$, unresolved), 1.48 and $1.32\left(3 \mathrm{H}\right.$ each, two s), $0.90(9 \mathrm{H}, \mathrm{s}), 0.11(6 \mathrm{H}, \mathrm{s}) .{ }^{13} \mathrm{C}\left(100 \mathrm{MHz}, \mathrm{CDCl}_{3}\right): 111.5$, 105.0, 85.6, 78.1, 77.1, 62.3, 26.8, 26.1, 25.7, 18.1, -5.5, -5.7.

5-O-tButyldimethylsilyl-1,2-O-isopropylidene- $\alpha$-L-ribofuranose 37 . To a magnetically stirred suspension of $\mathrm{CrO}_{3}(15.8 \mathrm{~g}, 158 \mathrm{mmol})$ in dry $\mathrm{CH}_{2} \mathrm{Cl}_{2}(250 \mathrm{~mL})$ was added pyridine, $(25.4 \mathrm{~mL}, 25 \mathrm{~g}, 316 \mathrm{mmol})$. The mixture warmed and 30 min later a solution of 35 (16 g, $52.6 \mathrm{mmol}$ in $\mathrm{CH}_{2} \mathrm{Cl}_{2}$ (70 mL) was added followed by $\mathrm{Ac}_{2} \mathrm{O}$ (14.9 mL, $16.1 \mathrm{~g}, 158 \mathrm{mmol})$. Slight warming took place again. $10 \mathrm{~min}$ later the reaction was quenched by addition of toluene - EtOAc mixture $(1: 1,300 \mathrm{~mL})$. The supernatant was drained and the black residue was washed with the same solvent mixture. The combined solutions were passed through a bed of silica gel prepared in toluene - EtOAc, 1:2. The fractions containing the ulose $36 R_{f} 0.44$ (hexane - EtOAc 17:3) were pooled together and the volatiles were evaporated. Co-evaporation with toluene was performed to expel residual pyridine. After brief drying on an oil pump, 96\% EtOH (150 mL) was added and the solution was cooled in an ice-bath. $\mathrm{NaBH}_{4}(5.1 \mathrm{~g}, 135 \mathrm{mmol})$ was added in one portion while maintaining magnetic stirring. $2 \mathrm{~h}$ later TLC showed the product $37 \mathrm{R}_{\mathrm{f}} 0.51$ (hexane - EtOAc 4:1). Acetone $(10 \mathrm{~mL}$ ) was added to destroy the excess of $\mathrm{NaBH}_{4}$ and 30 min later most of the volatiles were removed by evaporation. The residue was taken up in $\mathrm{CH}_{2} \mathrm{Cl}_{2}$ and washed with water. After conventional work-up (drying, flirtation, evaporation) and chromatography in hexane - EtOAc, 5:1, 37 as an oil (12.1g, 75.6\% for two steps) was obtained.

Exact mass: cal. for $\left[\mathrm{C}_{14} \mathrm{H}_{28} \mathrm{O}_{5} \mathrm{Si}+\mathrm{H}\right]^{+}=305.1779$, found: 305.1778 .

$[\alpha]_{D}^{26}-27.3$ (c $2.1 \mathrm{CHCl}_{3}$ ); lit. $^{77}$ for the D enantiomer: $[\alpha]_{\mathrm{D}}+30.7$ (c $1.1 \mathrm{CHCl}_{3}$ ). NMR ${ }^{1} \mathrm{H}\left(400 \mathrm{MHz}, \mathrm{CDCl}_{3}\right): 5.79$ $(1 \mathrm{H}, \mathrm{d}, J 3.8 \mathrm{~Hz}), 4.56(1 \mathrm{H}, \mathrm{dd}, J 4.1 \mathrm{~Hz}$ and $4.9 \mathrm{~Hz}), 3.99(1 \mathrm{H}, \mathrm{ddd}, J 5.2 \mathrm{~Hz}$ and $7.9 \mathrm{~Hz}$ and $9.5 \mathrm{~Hz}), 3.91(1 \mathrm{H}, \mathrm{dd}$, J $4.1 \mathrm{~Hz}$ and $12.6 \mathrm{~Hz}), 3.84-3.78(2 \mathrm{H}$, unresolved), $2.41(1 \mathrm{H}$, exchangeable, J $9.6 \mathrm{~Hz}), 1.57,1.37 \mathrm{two} \mathrm{s}, 3 \mathrm{H}$ each, $0.89(9 \mathrm{H}, \mathrm{s}), 0.08$ and 0.07 (two $s, 6 \mathrm{H}) .{ }^{13} \mathrm{C}\left(100 \mathrm{MHz} \mathrm{CDCl}_{3}\right): 112.5,104.2,81.2,78.8,71.2,61.8,26.6,25.9$, $18.4,-5.3,-5.4$.

\section{Acknowledgements}

Centro de Apoio à Pesquisa da UFRPE (CENAPESQ) and Departamento de Química Fundamental, UFPE, are appreciated for the exact mass measurements and the NMR spectra, respectively. Brazilian National Research Council (CNPq) is acknowledged for the scholarships for LJHT and NC. 


\section{References}

1. De Clercq, E. Int. J. Antimicrobial Agents 2009, 33, 307-320.

https://doi.org/10.1016/j.ijantimicag.2008.10.010

2. Mathé, C.; Gosselin, G. Antiviral Research 2006, 71, 276-281.

https://doi.org/10.1016/i.antiviral.2006.04.017

3. Malin, A. A.; Ostrovskii, V. A. Russ. J. Org. Chem. 2001, 37, 759-780.

https://doi.org/10.1023/A:1012441026853

4. Collins, P. M.; Ferrier, R. J. Monosaccharides. Their Chemistry and Their Roles in Natural Products. John Wiley \& Sons: Chichester, 1995.

5. Recondo, E.F.; Rinderknecht, H. Helv. Chim. Acta 1959, 42, 1171-1173.

https://doi.org/10.1002/hlca.19590420409

6. Visser, G.M.; van Westrenen, J.; van Boeckel, C. A. A.; van Boom, J. H. Recl. Trav. Chim. Pays-Bas, 1986, 105, 528-537.

https://doi.org/10.1002/recl.19861051203

7. Forsman, J. J.; Wärna, J.; Murzin, D. Y.; Leino, R. Eur. J. Org. Chem. 2009, 5666-5676.

https://doi.org/10.1002/ejoc.200900889

8. Ramamurty, C. V. S.; Ganney, P.; Rao, C. S.; Fraser-Reid, B. J. Org. Chem. 2011, 76, 2245-2247.

https://doi.org/10.1021/jo1021376

9. Köll, P.; Stenns, C.; Seelhorst, W.; Brandenburg, H. Liebig's Ann. Chem. 1991, 201-206.

https://doi.org/10.1002/jlac.199119910136

10. Sowden, J. Methods Carbohydr.Chem. Biochem. 1960, 1, 132-135 and references therein.

11. Milner, S. E.; Moody, T. S.; Maguire, A. R. Eur. J. Org. Chem. 2012, 3059-3067.

https://doi.org/10.1002/ejoc.201101840

12. Alvarez-Casao, Y.; Marquez-Lopez, E. ; Herrera, R. P. Symmetry 2011, 3, 220-245.

https://doi.org/10.3390/sym3020220

13. Palomo, C.; Oiarbide, M.; Laso, A. Eur. J. Org. Chem. 2007, 2561-2574.

https://doi.org/10.1002/ejoc.200700021

14. Luzzio, F. A. Tetrahedron 2001, 57, 915-945.

https://doi.org/10.1016/S0040-4020(00)00965-0

15. Monosaccharide Sugars. Chemical Synthesis by Chain Elongation, Degradation and Epimerization.

Györgydeák, Z.; Pelyvás, I. F. Academic Press: San Diego, 1998.

16. Lattová, E., Petrušová, M., Petruš, L., Chem. Papers, 1991, 45, 823-827.

17. Pham-Huu, D. P.; Petrušoá, M.; Petruš, L. Chem. Papers, 1998, 52, 235-237.

18. Petruš, L.; Petrušová, M.; Pham-Huu, D. P.; Lattová, E.; Pribulová, B.; Turjan, J. Chemical Monthly, 2002, 133, 383-392.

https://doi.org/10.1007/s007060200017

19. Keinan, E.; Mazur, Y. J. Am. Chem. Soc. 1997, 99, 3861-3862.

https://doi.org/10.1021/ja00453a067

20. Ballini, R.; Petrini, M. Tetrahedron Lett. 1989, 30, 5329-5332.

https://doi.org/10.1016/S0040-4039(01)93778-5

21. Olah, G. A.; Arvanaghi, M.; Vankar, Y. D.; Surya Prakash, G. K. Synthesis 1980, 662-663.

https://doi.org/10.1055/s-1980-29165 
22. Ballini, R.; Petrini, M. Adv. Synth. Catal. 2015, 357, 2371-2402.

https://doi.org/10.1002/adsc.201500008

23. Ballini, R.; Petrini, M. Tetrahedron 2004, 60, 1017-1047.

https://doi.org/10.1016/i.tet.2003.11.016

24. Nifontov, V. I.; Akishina, R. I.; Grishakov, A. N.; Yurkevich, A. M. Khim. Famaceut. Zh. 1987, 21, 599-611.

25. Baker, D. C.; Horton, D.; Tindall Jr, C. G. Carbohydr. Res. 1972, 24, 192-197.

https://doi.org/10.1016/S0008-6215(00)82279-X

26. Sowa, W.; Thomas, G. H. S. Can. J. Chem; 1960, 44, 836-838.

https://doi.org/10.1139/v66-120

27. Onodera, K.; Hirano, S.; Kashimura, N. J. Am. Chem. Soc. 1965, 87, 4651-4652.

https://doi.org/10.1021/ja00948a050

28. Hung, S. C.; Wang, C. C.; Thopate, S. R. Tetrahedron Lett. 2000, 41, 3119-3122.

https://doi.org/10.1016/S0040-4039(00)00363-4

29. Estevez, J. C.; Fairbanks, A. J.; Fleet, G. W. J. Tetrahedron 1998, 54, 13591-13620.

https://doi.org/10.1016/S0040-4020(98)00837-0

30. Mio, S.; Kumagawa, Y.; Sungai, S. Tetrahedron 1991, 47, 2133-2144.

https://doi.org/10.1016/S0040-4020(01)96124-1

31. Nutt, R. F.; Dickinson, M. J.; Holly, F. W.; Walton, E. J. Org. Chem. 1968, 33, 1789-1795.

https://doi.org/10.1021/jo01269a019

32. Lenagh-Snow, G. M. J.; Araújo, N.; Jenkinson, S. F.; Martínez, R. F.; Shimada, Y.; Yu, C. Y.; Kato, A.; Fleet,

G. W. J. Org. Lett. 2012, 14, 2142-2145.

https://doi.org/10.1021/ol300669v

33. Robins, M. J.; Sarker, S.; Samano, V.; Wnuk, S. F. Tetrahedron 1997, 53, 447-456.

https://doi.org/10.1016/S0040-4020(96)01035-6

34. Dahlman, O.; Garegg, P. J.; Mayer, H.; Schramek, S. Acta Chim. Scand. B 1986, 40, 15-20.

https://doi.org/10.3891/acta.chem.scand.40b-0015

35. Cruz-Gregorio, S. ; Hernández, L. ; Vargas, M. ; Quitero, L. ; Sartillo-Piscil, F. J. Mex. Chem. Soc. 2005, 49, 20-23.

36. Xie, X.; Berges, D. A.; Robins, M. J. J. Org. Chem. 1996, 61, 5178-5179.

https://doi.org/10.1021/jo960355u

37. Robins, M. J.; Doboszewski, B.; Timoshchuk, V. A.; Peterson, M. A. J. Org. Chem. 2000, 65, 2939-2945. https://doi.org/10.1021/jo991399g

38. Iodine Chemistry and Applications. Kaiho, T. ed. John Wiley \& Sons, Hoboken: New Jersey, 2015, chapter 32: pp 557-590; lodine Bioinorganic Chemistry: Physiology, Structures and Mechanisms, Küpper, F. C.; Kroneck, P. M. H.

39. Yamada, S.; Morizono, D.; Yamamoto, K. Tetrahedron Lett. 1992, 33, 4329-4332.

https://doi.org/10.1016/S0040-4039(00)74252-3

40. Doboszewski, B. J. Carbohydr. Chem. 2002, 21, 79-88.

https://doi.org/10.1081/CAR-120003739

41. Cimpoia, A. R.; Hunter, P. J.; Evans, C. A.; Jin, H.; Breining, T.; Mansour, T. J. Carbohydr. Chem., 1994, 13, 1115-1119.

https://doi.org/10.1080/07328309408011853

42. Niedballa, U.; Vorbrüggen, H. J. Org. Chem. 1974, 39, 3654-3660.

https://doi.org/10.1021/jo00939a008 
43. Holý, A.; Cech, D. Coll. Czech. Chem. Commun. 1974, 39, 3157-3167.

https://doi.org/10.1135/cccc19743157

44. Mukaiyama, T.; Matsutani, T.; Shimomura, N. Chem. Lett. 1993, 1627-1630.

https://doi.org/10.1246/cl.1993.1627

45. Chow, K.; Danishefsky, S. J. Org. Chem. 1990, 55, 4211-4214.

https://doi.org/10.1021/jo00300a049

46. Liao, J.; Sun, J.; Yu, B. Tetrahedron Lett. 2008, 49, 5036-5038.

https://doi.org/10.1016/j.tetlet.2008.06.042

47. Liu, G.-j.; Zhang, X.-t.; Xing, G.-w. Chem. Commun. 2015, 51, 12803-12806.

https://doi.org/10.1039/C5CC03617H

48. Lewis, A. F.; Revankar, G. R.; Hogan, M. E. J. Heterocycl. Chem. 1993, 30, 1309-1315.

https://doi.org/10.1002/ihet.5570300522

49. Winum, J.-Y.; Kamal, M.; Barragan, Y.; Leydet, A.; Montero, J.-L. Synth. Commun. 1998, 28, 603-606. https://doi.org/10.1080/00397919808005931

50. Zhang, Q.; Sun, J.; Zhu, Y.; Zhang, F.; Yu, B. Angew. Chem. Int. Ed. 2011 50, 4933-4936. https://doi.org/10.1002/anie.201100514

51. Agrofoglio, L. A.; Jacquinet, J. C.; Lancelot, G. Tetrahedron Lett. 1997, 38, 1411-1412. https://doi.org/10.1016/S0040-4039(97)00080-4

52. Ogawa, T.; Matsui, M. J. Organomet. Chem. 1978, 145, C37-C40. https://doi.org/10.1016/S0022-328X(00)81311-X

53. Crossey, K.; Cunningham, R. N.; Redpath, P.; Migaud, M. E. RSC Adv. 2015, 5, 58116-58119. https://doi.org/10.1039/C5RA12239B

54. Hu, C.; Li, L.; Zheng, Y.; Rui, L.; Hu. C. Appl. Microbiol. Biotechnol. 2011, 92, 449-455. https://doi.org/10.1007/s00253-011-3552-4

55. Okano, K. Tetrahedron 2009, 65, 1937-1949. https://doi.org/10.1016/j.tet.2008.11.047

56. Bílik, V.; Knězek, I. Chem. Papers 1992, 46, 193-195.

57. Angyal, S. J. Aust. J. Chem. 2005, 58, 58-59. https://doi.org/10.1071/CH04201

58. Perali, R. S. ; Mandava, S. ; Bandi, R. Tetrahedron 2011, 67, 4031-4035. https://doi.org/10.1016/i.tet.2011.04.012

59. Shi, Z.-D. ; Yang, B.-H. ; Wu, Y.-L. Tetrahedron 2002, 58, 3287-3296.

https://doi.org/10.1016/S0040-4020(02)00230-2

60. Fan, A.; Jaenicke, S.; Chuah, G.-K. Org. Biomol. Chem. 2011, 9, 7720-7726. https://doi.org/10.1039/c1ob06116j

61. Jung, M. E.; Xu, Y. Tetrahedron Lett. 1997, 38, 4199-4202.

https://doi.org/10.1016/S0040-4039(97)00870-8

62. Yun, M.; Moon, H. R.; Kim, H. O.; Choi, W. J.; Kim, Y.-C.; Park, C.-S.; Jeong, L. S. Tetrahedron Lett. 2005, 46, 5903-5905.

https://doi.org/10.1016/j.tetlet.2005.06.117

63. Doboszewski, B.; Herdewijn, P. Tetrahedron Lett. 2012, 53, 2253-2256. https://doi.org/10.1016/j.tetlet.2012.02.091

64. Szarek, W. A.; Hay, G. W.; Vyas, D. M.; Ison, E. R.; Hronowski, L. J. J. Can. J. Chem. 1984, 62, 671-674. https://doi.org/10.1139/v84-112 
65. Eliel, E. L.; Wilen, S. H.; Mander, L. N. Stereoselective Synthesis. Stereochemistry of Organic Compounds; John Wiley \& Sons, Inc.: New York, 1994; pp 835-990.

66. Lecea, B.; Arrieta, A.; Morao, I.; Cossio, F. P. Chem. Eur. J. 1997, 3, 20-28. https://doi.org/10.1002/chem.19970030105

67. Einhorn, C.; Luche, J.-L. Carbohydr. Res. 1986, 155, 258-261. https://doi.org/10.1016/S0008-6215(00)90155-1

68. Harwood, L. M. Aldrichim. Acta, 1985, 18, 25.

69. Pedersen, D. S.; Rosenbohm, C. Synthesis 2001, 2431-2434.

70. Moravcová, J.; Čapková, J.; Staněk, J. Carbohydr. Res. 1994, 263, 61-66. https://doi.org/10.1016/0008-6215(94)00165-0

71. Moyroud, E.; Strazewski, P. Tetrahedron 1999, 55, 1277-1284. https://doi.org/10.1016/S0040-4020(98)01119-3

72. Chelain, E.; Floch, O.; Czarnecki, S. J. Carbohydr. Chem. 1995, 14, 1251-1256. https://doi.org/10.1080/07328309508005408

73. Tsutsumi, H.; Kawai, Y.; Ishido, Y. Carbohydr. Res. 1979, 73, 293-296. https://doi.org/10.1016/S0008-6215(00)85502-0

74. Sivets, G. G.; Klennitskaya, T. V.; Zhernosek, E. V.; Mikhailopulo, I. A. Synthesis 2002, 253-259. https://doi.org/10.1055/s-2002-19805

75. Beránek, J. ; Hřebanecký, H. Nucleic Acids Res. 1976, 3, 1387-1399. https://doi.org/10.1093/nar/3.5.1387

76. Lerner, L. M. Carbohydr. Res., 1975, 44, 13-21. https://doi.org/10.1016/S0008-6215(00)84331-1

77. Dvorakova, M.; Pribylova, M.; Pohl, R.; Migaud, M. E.; Vanek, T. Tetrahedron 2012, 68, 6701-6711. https://doi.org/10.1016/j.tet.2012.05.117

78. Bordier, A.; Compain, P.; Martin, O. R.; Ikeda, K.; Asano, N. Tetrahedron: Asymmetry 2003, 14, 47-51. https://doi.org/10.1016/S0957-4166(02)00752-8

79. Doboszewski, B.; Herdewijn, P. Tetrahedron 2008, 64, 5551-5562. https://doi.org/10.1016/j.tet.2008.03.088 